\title{
Biochemical Composition of Chlorella Sorokiniana Grown in a Novel Design of Hybrid Photobioreactor
}

Renata Natsumi Haneda ${ }^{1 *}$, Bruna Horvat Vieira ${ }^{2}$, Sérgio Rodrigues Fontes ${ }^{3}$, Geraldo Ombardi ${ }^{3}$, Carlos Aparecido Casali ${ }^{1}$ and Ana Teresa Lombardi ${ }^{1}$

${ }^{1}$ Department of Botany, Federal University of São Car los, Rodovia Washington Luis Km 235, São Carlos, São Paulo, Brazil

${ }^{2}$ Center for Water Resources and Applied Ecology, University of São Paulo, Avenida Trabalhador São-carlense 400, São Carlos, São Paulo, Brazil

${ }^{3}$ Department of Mechanical Engineering, University of São Paulo, Avenida Trabalhador São-carlense 400, São Carlos, São Paulo, Brazil

\begin{abstract}
The aim of this study was to assess the feasibility of a $180 \mathrm{~L}$ photobioreactor in which a submerged ultrafiltration system was used to maintain continuous nutrient inflow without biomass loss from the culture. After exponential growth, approximately $15 \%$ of the total volume was removed and replaced with a modified medium to induce algal physiological responses as a biochemical manipulation procedure. In this system, Chlorella sorokiniana was kept under healthy conditions, according to protein: carbohydrate ratio. C. sorokiniana was grown exponentially for 4 days up to $8.9 \times 10^{6}$ cells $\mathrm{mL}^{-1}$. The culture medium used for biochemical manipulation $(72 \mathrm{~h}$ exposure) consisted of LC Oligo medium without nitrates or phosphates, and with $7 \times 10^{-7} \mathrm{molL}^{-1}$ total copper. The results confirmed the effectiveness of the submerged membrane and showed that algae exposure to a stressing medium resulted in intracellular carbohydrate increase, thus protein: carbohydrate $(P: C)$ ratios, and affected lipid class composition. This novel photobioreactor configuration has the potential to improve microalgal yields and/or specific intracellular constituents, inasmuch as biochemical manipulation of the biomass is facilitated and the continuous system is operated without biomass loss.
\end{abstract}

Keywords: Hybrid photobioreactor; Lipid classes; Carbohydrates; Proteins; Copper; Nutritional stress; Chlorella sorokiniana

\section{Introduction}

Microalgae have wide range of applications in pharmaceutical, cosmetic, and food industries $[1,2]$ In addition, these organisms have high growth rates and the capacity to adapt themselves to changes in environmental conditions by producing a variety of biomolecules, which is known as physiological plasticity [3-5].

During microalgal growth in batch cultures, chemical and physical variations in cell surroundings can affect photosynthetic efficiency [6] and $\beta$ biochemical composition $[3,7,8]$ argued that such effects can be expected because cell division decreases and carbon is allocated to lipids and carbohydrates, so these molecules are increased at the expense of proteins.

The quality of the biomolecules of interest is particularly important when the final product is subject to regulatory oversight [9]. However, batch culture does not offer such stability, which can result in undesirable variations from batch to batch in a production system. A photobioreactor that furnish constant growth conditions and reproducible conditions for manipulation of the biomass composition can be suitable for large scale production of microalgae. In theory, continuous culture would result in biomass of more constant composition than batch growth. According to [10], one of the impediments to the commercial use of high-density photoautotrophic algal cultures for the production of high-value products is the availability of suitable photobioreactors. Open ponds and closed photobioreactors share the problems of microalgae harvesting and growth medium enrichment that together contribute to the high cost of algal biomass production [11,12]. Open ponds are also predisposed to culture contamination. Continuous or semi-continuous systems applied to closed photobioreactors for algal culture is one of the best methods to maintain cultures close to their maximum growth rate, hence under healthy physiological conditions [6]. Continuous cultures have the advantage of producing algae of more predictable quality (biochemical composition) and keeping cells under healthy conditions for longer periods than batch or fed-batch systems. In addition, continuous systems are amenable to technological control and automation, increasing the reliability of the system and reducing labor cost [13]. However, continuous systems also have disadvantages, such as relatively high cost and complexity.

Considering the above mentioned difficulties and to make cultivation of microalgae in large scale economically feasible, membrane processes have long been tested in different stages of microalgae cultivation and processing with positive results [14-16]. Most existing large-scale microalgal plant systems still use energyintensive centrifuges to harvest microalgae. Besides the often claimed lower energy consumption, especially for a submerged system [17], membrane filtration also offers the possibility of permeate recirculation without the accumulation of chemicals from flocculating agents, as encountered in the coagulation/flocculation technique [18]. According to Hwang et al. hydrophilic membranes are more resistant to fouling. However, it may depend strongly on the microalgal species too, since they excrete different amounts and types of organic materials that adhere onto surfaces are known to play important role in membrane fouling [14].

In this research we propose a novel system for microalgal growth whose important characteristic is the coupling of continuous cultures

*Corresponding author: Renata Natsumi Haneda, Department of Botany, Federal University of São Car los, Rodovia Washington Luis Km 235, Brazil, Tel: +55 16997295570; fax: + 55 1633744827; E-mail: renatanathaneda@gmail.com

Received March 06, 2015; Accepted March 24, 2015; Published March 31, 2015

Citation: Haneda RN, Vieira BH, Fontes SR, Ombardi G, Casali CA, et al. (2015) Biochemical Composition of Chlorella Sorokiniana Grown in a Novel Design of Hybrid Photobioreactor. J Microb Biochem Technol 7: 076-082. doi:10.4172/19485948.1000185

Copyright: (C) 2015 Sujata Sirsat A, et al. This is an open-access article distributed under the terms of the Creative Commons Attribution License, which permits unrestricted use, distribution, and reproduction in any medium, provided the original author and source are credited 
without biomass loss. The algae were cultured in semi-closed units, permitting evaporation as a means of heat dissipation, in continuous or semi-continuous cultivation mode, so that microalgae are kept under ideal growth conditions, and without biomass loss owing to a submerged polymeric membrane that is used to permeate used medium while retaining the biomass. Culture medium change for further biochemical manipulation of the biomass is conveniently done through membrane permeation. The polymeric membrane also permits biomass concentration prior to biomass harvesting. It is a reusable and commercially available membrane.

\section{Material and Methods}

\section{Stock cultures}

Chlorella sorokiniana (211-32) was kindly furnished by the Institute of Plant Biochemistry and Photosynthesis (IBVF), University of Sevilla, Spain. Stock batch cultures $(200 \mathrm{~mL})$ were kept in modified LC Oligo medium (AFNOR, 1980) under laboratory controlled conditions of light intensity $\left(150 \mu \mathrm{E} \mathrm{m}^{-2} \mathrm{~s}^{-1}\right)$, light/dark cycle (12:12 hours), and temperature $\left(24 \pm 2^{\circ} \mathrm{C}\right)$, at pH 7 (Logen Scientific, LS 300-HH, Brazil).

\section{Inocula preparation}

Inocula for the $180 \mathrm{~L}$ photobioreactors were prepared in a scaleup system. C. sorokiniana was grown in $20 \mathrm{~L}$ low density polyethylene photobioreactors, in which culture medium was supplemented daily up to a final cell density of 106 cells $\mathrm{mL}^{-1}$. This was further inoculated in the $180 \mathrm{~L}$ photobioreactor. Therefore, initial cell density of $180 \mathrm{~L}$ culture was 105 cells $\mathrm{mL}^{-1}$. The choice of 106 cells $\mathrm{mL}^{-1}$ maximum inoculum density was based on the results of Lombardi and Maldonado [6] that showed that 106 cells $\mathrm{mL}^{-1}$ is the maximum density permitted for high photosynthetic efficiency, a measurement microalgae health status. Thus, healthy beginning of the $180 \mathrm{~L}$ cultures was guaranteed by carefully controlling the inoculum density and cells' physiological conditions

\section{Photobioreactor and ultra filtration system}

A photobioreactor, referred here as hybrid photobioreactor (HPBR), was used for the experiments. A schematic diagram of the unit is shown in Figure 1. It consisted of a glass tank, a mechanical mixing device, a $\mathrm{CO}_{2}$ (3\%)/air (97\%) bubbling system installed below the membrane, a supply of fresh culture medium fed by a peristaltic pump and an ultrafiltration system. The mixing device was composed of a mechanical mixer (Fisatom, 713DS, Brazil) and

a propeller. Culture tank dimensions were $0.8 \mathrm{~m}$ length, $0.5 \mathrm{~m}$ width, $0.8 \mathrm{~m}$ depth with $180 \mathrm{~L}$ working volume; an air space of $0.08 \mathrm{~m}$ was maintained in the HPBR, so that the depth of culture medium was $0.72 \mathrm{~m}$. For temperature regulation, water evaporated from the surface of culture medium, condensed on the lid and dropped back into the HPBR. In the conditions used, heat dissipation through this mechanism was enough for cells to keep on its maximum growth. Inside the HPBR there was a hydrophilic polyether sulfone membrane to process ultrafiltration with $0.6 \mathrm{~m} 2$ filtration area and $0.005 \mu \mathrm{m}$ pore size and a hydraulic circuit to collect the permeate. To operate the HPBR as a continuous flow system, the polymeric membrane was employed to remove used growth medium free of microalgal cells (confirmed under light microscope), while a peristaltic pump (Masterflex, Model 7712222, USA) introduced fresh culture medium. Culture $\mathrm{pH}$ was adjusted daily to $\mathrm{pH} 7.0$ through the $\mathrm{CO}_{2}$ : air bubbling.

\section{Photobioreactor cultures}

The $180 \mathrm{~L}$ photobioreactor was placed in a greenhouse under semicontrolled environmental conditions. Natural illumination varied from $300 \mu \mathrm{E} \mathrm{m}^{-2} \mathrm{~s}^{-1}$ to $1200 \mu \mathrm{E} \mathrm{m}^{-2} \mathrm{~s}^{-1}$ and temperature control was promoted by exhausters and humid refrigeration systems. Culture temperatures varied within $20-28^{\circ} \mathrm{C}$. The photobioreactor was operated as both continuous and batchculture modes at different moments in a unique culture module. First, a continuous system

maintained healthy growth conditions for microalgae through continuous flow of fresh culture media. For the continuous culture mode, the ultrafiltration system was operated continuously to permeate approximately $2 \mathrm{~L} \mathrm{day}^{-1}$ in constant pressure without cell loss during 5 days. In this case, hydraulic pressure of the culture column above the membrane promoted the permeation. A ball valve was installed in the hydraulic circuit of the ultrafiltration system to control permeate output with no volume change of the culture during the 5 days. On the 6th day, the continuous input of fresh culture medium was ceased and $30 \mathrm{~L}$ of used medium were removed through the complete opening of the valve. This allowed a maximum initial flow of permeate of 40 $\mathrm{L} \mathrm{h}^{-1} \mathrm{~m}-2 \pm 10$ and a steady-state flux at the end of the ultrafiltration process of $4 \mathrm{~L} \mathrm{~h}^{-1} \mathrm{~m}^{-2} \pm 15.1$. In this case, the pressure was not constant and flow rate decreased along permeation time. At every ten minutes the permeate flux was collected in order to evaluate its flux as function of time [19]. A summary of the fluid-dynamic conditions is given in Table 1 .

After ultrafiltration, $30 \mathrm{~L}$ of fresh LC Oligo culture medium without nitrate and phosphate, plus $7 \times 10^{-7}$ mol L $\mathrm{L}^{-1}$ copper was fed into the photobioreactor to induce intracellular physiological transformation, such as biochemical synthesis of storage molecules. In this condition, the culture was operated in batch mode for $72 \mathrm{~h}$. The experiment lasted

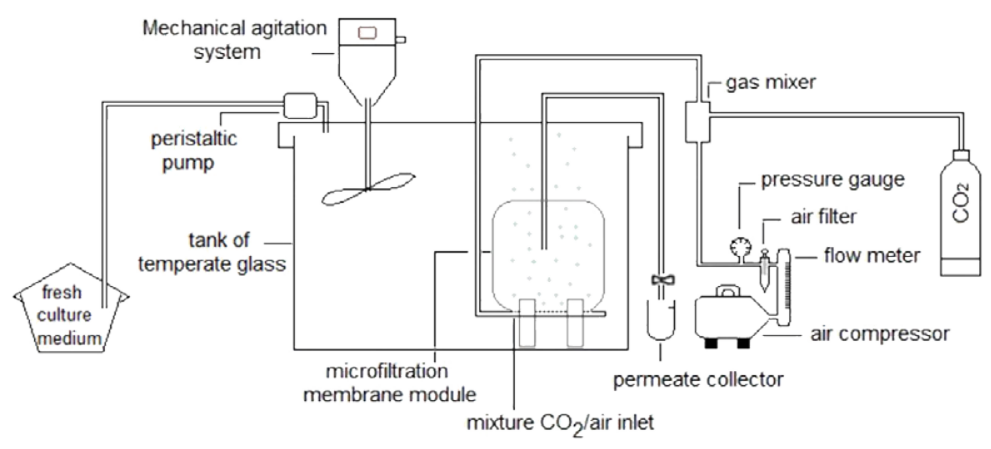

Figure 1: Schematic diagram of the hybrid photobioreactor (HPBR) used in this study. 


\begin{tabular}{|c|c|c|c|c|}
\hline Culture Phases & Pressure transmembrane & Filtration time (h) & Initial permeate flux $\left(\mathrm{L} \mathrm{h}^{-1} \mathrm{~m}^{-2}\right)$ & Final permeate flux $\left(\mathrm{L} \mathrm{h}^{-1} \mathrm{~m}^{-2}\right)$ \\
\hline Continuous system (First 5 days) & Constant & 120 & 0.14 & 0.14 \\
\hline $30 \mathrm{~L}$ medium removal & Variable & 6 & 40 & 4.0 \\
\hline
\end{tabular}

Table 1: Processing parameters of the ultrafiltration experiments.
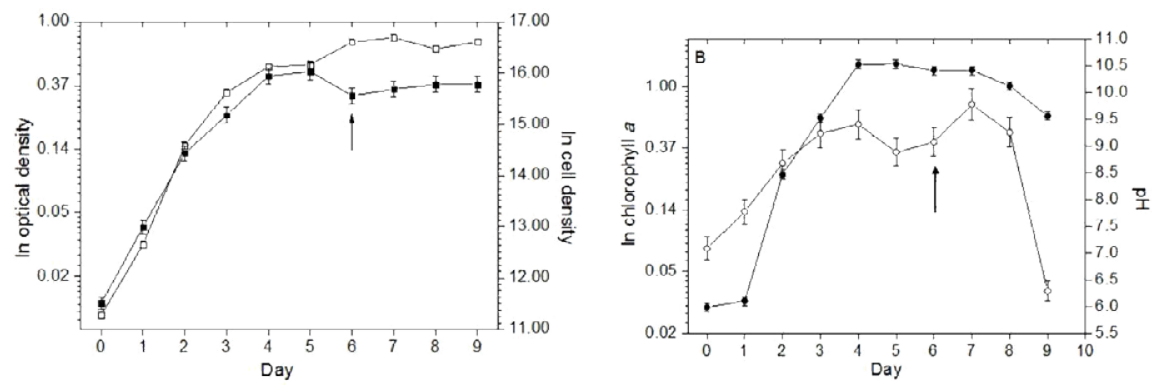

Figure 2: ( $\mathrm{A}$ ) Optical density (684 nm, natural logarithm; empty squares) and cell density (natural logarithm;full squares); (B) clorophylla (natural logarithm, full circles) and $\mathrm{pH}$ (empty circles) during Chlorellasorokiniana growth in the $200 \mathrm{~L}$ hybrid photobioreactor. Continuous system was used up to day 5; arrowindicates exchange of $30 \mathrm{~L}$ used media with stressing medium (extra copper added).

9 days and cultures were sampled daily for optical and cell density, chlorophyll a concentration, $\mathrm{pH}$, intracellular lipids, proteins and carbohydrates before and after culture medium exchange.

\section{Cleaning procedure}

The recovery of permeate flux is only possible after a chemical cleaning of the membrane [20]. In this case, at the end of the experiment, the system was rinsed with tap water with no chlorine to remove the polarized layer deposited on membrane surface. Subsequently, 0.5\% alkaline detergent Extran MA 01 (Merck KGaA, Darmstadt, Germany) at environmental temperature was circulated through the system during 60 minutes, after which it was rinsed with chlorine free tap water to completely remove the detergent. After this, a chlorine solution with $1 \%$ of sodium hypochlorite $(\mathrm{NaClO})$ was circulated during 30 minutes, and finally the system was rinsed with chlorine free tap water. This cleaning procedure was performed between experiments and membrane performance checked through the mean time needed to remove $30 \mathrm{~L}$ of permeates $(\sim 6 \mathrm{~h})$. Membrane performance was consistent throughout this study.

\section{Physicochemical analysis}

Chlorophyll a concentrations were determined by in vivo fluorescence, using a Turner Fluorometer (Promega Corporation, USA). Before measurements, culture samples were dark adapted for 20 minutes and chlorophyll a content determined considering a calibration curve, where chlorophyll a concentration $\left(\mathrm{mg} \mathrm{L}^{-1}\right)$ was plotted against fluorescence intensity. Optical density was measured at $684 \mathrm{~nm}$ with a UV-VIS scanning spectrophotometer

(FEMTO 800 XI, Brazil). Cell density was determined by cells counting (samples in 5\% acid Lugol solution) in a bright lined FuchsRosenthal hemacytometer under optical microscope. Specific growth rates were obtained by plotting the natural logarithm of in vivo fluorescence intensity against experimental time and calculating the slope of the linear part of the curve by linear regression.

Total intracellular carbohydrates were quantified according to the modified phenol-sulfuric acid methodology described in [21], using glucose as standard. Total intracellular proteins were determined according to the procedure of [22] using bovine serum albumin (BSA) as standard and Coomassie Brilliant Blue G-250 as protein reagent.
Protein extraction was performed as described by [23] using $0.5 \mathrm{~N}$ $\mathrm{NaOH}$.

Lipid classes were quantified by Thin Layer Chromatography with Flame Ionization Detection using an Iatroscan TLC-FID (Iatron Laboratories Inc., Tokyo, Japan). Lipids were extracted twice in chloroform/methanol (2:1) and hexadecane-3-one was used as internal standard [24]. For lipid analysis, samples were concentrated in a rotary evaporator (RV05 S25, IKA, Germany). Concentrated lipid samples were spotted onto silica gel-coated rods (Chromarods-SIII), focused twice in acetone and scanned under the analytical conditions of $173 \mathrm{~mL}$ $\min ^{-1}$ hydrogen flow, $2 \mathrm{~L} \mathrm{~min}^{-1}$ air flow and $4 \mathrm{~mm} \mathrm{~s}^{-1}$ scan speed. Lipid classes were identified by their retention times, compared to Sigma standards, and estimated from peak areas recorded and processed by Peak Simple software version 3.93 (SRI Instruments, Menlo Park, California, USA).

\section{Results}

Population density (cell $\mathrm{mL}^{-1}$ ), optical density, chlorophyll a content and $\mathrm{pH}$ are plotted against experimental time in Figure 2. Optical density varied from 0.01 to 0.5 A.U, $\mathrm{pH}$ within 6.0 and 9.0 and chlorophyll a content from $0.02 \mathrm{mg} \mathrm{L}^{-1}$ to $1.44 \mathrm{mg} \mathrm{L}^{-1}$. These results indicated that during continuous cultivation, exponential growth of $C$. sorokiniana was maintained up to the 4 th culture day, during which cell density increased from 105 cells $\mathrm{mL}^{-1}$ to $9.3 \times 106$ cells $\mathrm{mL}^{-1}$ and the specific growth rate was $1.10 \mathrm{~d}-1$ for C. sorokiniana.

The use of the submerged ultrafiltration membrane enabled culture medium exchange through which $15 \%$ of total volume was removed. This process led to - approximately $2.7 \times 106$ cells $\mathrm{mL}^{1}$ becoming attached to the membrane surface, thereby decreasing the population density and polarizing the membrane. This was further confirmed by a decline in chlorophyll a content from $1.44 \mathrm{mg} \mathrm{L}^{-1}$ to $1.30 \mathrm{mg} \mathrm{L}^{-1}$. Microscopic observations confirmed the absence of $C$. sorokiniana cells in the permeate. After $48 \mathrm{~h}$ of biochemical manipulation cell density rose, but $24 \mathrm{~h}$ later, cells began to aggregate and settle on the bottom of the photobioreactor. This event was followed by culture collapse, which was confirmed by sharp $\mathrm{pH}$ decrease (Figure 2). Protein: carbohydrate ratios confirmed the healthy condition of the controls (P:C 6.97), decreasing thereafter to 0.45 ( $24 \mathrm{~h}), 0.29$ ( $48 \mathrm{~h}), 0.39$ (72 h).

Figure 3 shows the relative lipid class composition. Exposure of 


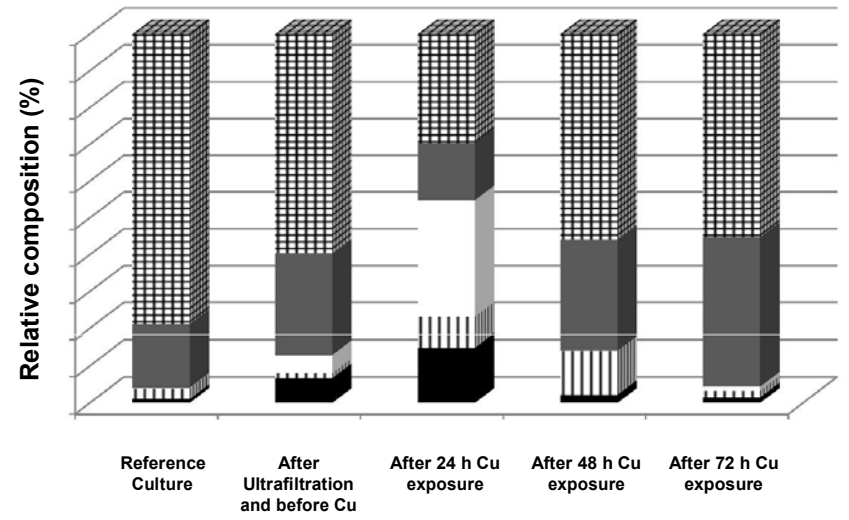

Figure 3: Bar graph showing the relative composition of lipid classesfor the several culture conditions.

Reference culture, after ultrafiltration and before biochemical manipulation, after $24 \mathrm{~h}$ biochemical manipulation, after $48 \mathrm{~h}$ biochemical manipulation and after $72 \mathrm{~h}$ biochemical manipulation. Bar patterns: Black=aliphatic hydrocarbons, stripe=free sterol, white=triacylglycerol, gray=acetone mobile polar lipids, grid=phospholipids.

culture to medium without $\mathrm{N}$ and $\mathrm{P}$, and extra copper affected cell physiology and its biochemical composition. Under healthy growth conditions, the structural lipids acetone mobile polar lipids (AMPL) and phospholipids (PL) dominated, but after $24 \mathrm{~h}$ of biochemical manipulation, aliphatic hydrocarbons (HC 15\%), free sterols (ST $8 \%$ ) and triglycerides (TG 30\%) increased at the same time that AMPL and PL decreased. Adaptation of the microalgae to the biochemical manipulation used to induce intracellular synthesis of biomolecules was confirmed by the return to almost normal values of the AMPL and PL lipid classes at 48 and $72 \mathrm{~h}$. Free fatty acids (FFA), wax ester (WE) and free aliphatic alcohol (ALC) were present in trace amounts (0-1\% of total lipids), so data are not shown.

\section{Discussion}

The $\mathrm{pH}$ variation $(7.0$ - 9.8) observed in the $180 \mathrm{~L}$ C. sorokiniana culture is in accordance with literature data for other Chlorella cultures $[25,26]$. This is explained by the consumption of nitrate and dissolved inorganic carbon species [27,9]. $\mathrm{CO}_{2}$ bubbling that was used for $\mathrm{pH}$ control supported a hundred fold increase in biomass, from 105 to $\sim 107$ cells $\mathrm{mL}^{-1}$ in 4 days. Compared to literature data, the present results showed the greatest cell density increase, which can be related both to $\mathrm{CO}_{2}$ bubbling and the nutrient influx provided by continuous feed of fresh medium during the exponential growth phase without biomass loss. [28] observed a 12.5 times increase in Chlorella sp. cell density (from $8 \times 10^{6}$ to $1 \times 10^{8}$ cells $\mathrm{mL}^{-1}$ ) after 8 days of growth at $2 \% \mathrm{CO}_{2}$ bubbling [29] Studied Chlorella vulgaris growth in residual hydroponic solution and found that cell density increased 100 times in 8 days, from 105 to 107 cells $\mathrm{mL}^{-1}$, after which $\mathrm{pH}$ reached 9.5, indicating that high $\mathrm{CO}_{2}$ absorption accomplished. Note that the final cell density of 107 cells $\mathrm{mL}^{-1}$ obtained in this photobioreactor is very much similar to those obtained under controlled conditions in our laboratory, with LC Oligo culture medium.

Culture medium renewal using the ultrafiltration membrane presupposes removal of medium in the shortest time possible. In the present research, $15 \%$ of the medium was removed for the biochemical manipulation, with the membrane being used at its maximum permeation capacity. This led to algae fouling on membrane surface, which was detected as cell density decrease on the $6^{\text {th }}$ culture day. According to [30], who used similar membranes for Chlorella filtration, the cake layer of Chlorella cells on membrane surface would not cause resistance higher than the membrane resistance itself if cells were not compressed. In this situation, membrane fouling may be attributed to the fact that initially, when cells are in low number, there is no compaction and, hence, no significant resistance. However, when the amount of algal cells being deposited on membrane surface increase, the extent of cell compaction increases at its maximum. This is controlled by the transmembrane pressure being applied as well as by algal cell shape and chemical surface interactions with the ultrafiltration membrane pores.

Babel and Takizawa [30] showed that, after maximum compaction, cake resistance increased linearly with the amount of cake. Therefore, air bubbling has been tested as a solution for membrane fouling, in which the coarse bubbles aeration generates direct shear on the membrane surface by inducing a secondary flow of liquid. This disrupts the mass transfer boundary layer, and promotes local mixing near the membrane surface [31,32].

In the present paper, during the continuous system, low permeate flux was maintained around $0.14 \mathrm{~L} \mathrm{~h}^{-1} \mathrm{~m}^{-2}$ for five days. This flux was much lower than steady-state flux $\left(4 \mathrm{~L} \mathrm{~h}^{-1} \mathrm{~m}^{-2}\right)$. In the continuous flow, low permeate flux, gas bubbling and culture mixing were essential factors to limit membrane fouling. Despite the bubbling aid to decrease membrane fouling, when the valve was fully opened to permit maximum permeation, a continued and accented decrease of the permeate flux was observed.

In the present research, during the $30 \mathrm{~L}$ medium removal, air bubbling was tested for $C$. sorokiniana removal from the membrane surface. These results showed that although there was less membrane fouling, the bubbling promoted algal stress and death. Therefore, during the $30 \mathrm{~L}$ medium removal, only gentle bubbling with $\mathrm{CO}_{2} /$ air mixture was used; the role of $\mathrm{CO}_{2}$ /air bubbling in the culture system was exclusively for $\mathrm{pH}$ control, which was performed once a day throughout the experiment.

Chlorophyll a concentration varied from 280 pg cell- 1 in the control to $87 \mathrm{pg}$ cell-1 after $72 \mathrm{~h}$ exposure to the biochemical manipulation culture medium containing, representing a decrease of $\sim 3$ times. These results agree with those of Bajguz [33] that observed lower chlorophyll a content in stressed microalgae in comparison with the control.

The biochemical composition and P:C ratio of phytoplankton have been shown to be related to their nutritional status [34-36]. According to Healey and Hendzel, [37] an increase in P:C ratio is evidence of healthy cells, whereas its decrease an unhealthy or stressing condition. Thus, in the present results for C. sorokiniana at the beginning of exponential growth, when P:C ratio was 6.97 , denotes healthy cells, whereas the P:C ratio decrease to 0.39 after $72 \mathrm{~h}$ exposure to the stressing culture medium denotes stressed cells. These results are in accordance with those of Ho [38], who observed a P:C ratio decrease from 4.4 to 0.37 for Chlorella vulgaris FSP-E during nitrogen starvation period in modified Basal medium. Ji [39] found a P: C ratio of 5.2 for Chlorella vulgaris cultured in 100-fold diluted monosodium glutamate wastewater (MSGW) and a P:C ratio of 1.79 with 800-time diluted MSGW. Similarly, in experiments of culture medium reuse, Rocha [40] obtained a ratio of 5.18 for Scenedesmus quadricauda control cultures, while in stressing conditions the authors obtained P:C ratios of $\sim 1.0$. Besides its variation with nutritional condition, it is also expected that the $\mathrm{P}: \mathrm{C}$ ratio varies with different algal species.

We calculated P:C ratios from the biochemical composition data 
presented in Illman [41], whose experiments were performed in batch cultures, and obtained approximate values of 0.57 for Chlorella vulgaris, 0.78 for $C$. emersonii, 0.73 for $C$. protothecoids, 1.18 for $C$. sorokiniana and 0.57 for C. minutissima. The higher level of protein in relation to carbohydrates observed in our P:C ratio in comparison to those calculated from the results of Illman[41] can be attributed to the different growth conditions furnished by continuous and batch systems, indicating a better physiological status in the first. The P:C ratios around 0.5 , denoting that at least twice as much carbohydrates as proteins was present during culture manipulation with the modified culture medium in the present research, confirmed that cells were stressed. This is in agreement with several authors that showed reduced protein content in stressed cells, such as Lourenço [42] and Zhao [43] investigated the distribution of intracellular $\mathrm{N}$ in marine microalgae and showed that N-limited cells had lower protein content than the controls. Zhao [43] showed that nutrient stressed Skeletonema costatum had lower total proteins content than cells kept in high nutrient conditions. These authors showed that carbohydrates accumulated under $\mathrm{N}$ and $\mathrm{P}$ limitation, in which the highest carbohydrates content was obtained in cells grown with $64 \mu \mathrm{M} \mathrm{N}$ and $36 \mu \mathrm{M}$ P.

It is well documented that lipids and carbohydrates are storage molecules, while proteins are structural biomolecules. Thus, an increase either in lipid or in carbohydrate content suggests phytoplankton cells can be in asituation unfavorable for growth. Several recent reports [4446] have demonstrated that, under conditions of nitrogen-depletion, intracellular proteins can be transformed into lipids or carbohydrates in microalgae.

It is known that copper affects photosynthesis [6], growth rates [47] and chlorophyll $a$ content in phytoplankton. In excess it disturbs important physiological functions and enzymes, interfering with cell biochemistry, including membrane integrity. The effects of copper on photosynthetic organisms include interference with fatty acids, membrane lipids, protein metabolism and inhibition of respiration and nitrogen fixation processes [48]. Similarly to the present results, the accumulation of carbohydrates in phytoplankton stressed by copper has been reported $[49,50]$.

Contrary to what has been reported in several published data, the present results showed a reduction in lipid production/unit volume during and after culture manipulation. Several studies show lipid increase under nutrient stress $[4,5,35,51,52]$. Triacylglycerol (TG) accumulation was seen in Stephanodiscus minutulus when the cells were grown under $\mathrm{Si}, \mathrm{N}$ or $\mathrm{P}$ limitation, while polar lipids decreased [53]. However, the present results agree with those of Xin [54], who did not obtain lipid accumulation in $\mathrm{N}$ or $\mathrm{P}$ limited Scenedesmus sp. cultures. Similarly, [55] demonstrated that combinations of stress factors can, under certain circumstances, inhibit neutral lipid synthesis. The authors investigated lipid synthesis in Nannochloropsis sp.

Regarding relative lipid composition, the present results showed that phospholipids (PL-membrane lipids) and a pigment class, acetone mobile polar lipids (AMPL), constituted most of the total lipids detected in C. sorokiniana under any growth conditions. This is in accordance to most literature data, which have shown that high concentrations of PL and AMPL, relative to other lipid classes, are expected in microalgae [56,57] and Parrish and Wangersky [58] investigated lipid class production in several marine phytoplankton and reported these lipid classes as major constituents ( 70-80\%). Similarly, Chia [4] reported high percent contribution of PL and AMPL to total lipids in Chlorella $s p$. However, TG increase denotes stressing conditions, and according to [57], any TG content higher than $15 \%$ of the total lipids can imply nutrient stress, which can justify the increase in TG after $24 \mathrm{~h}$ exposure to the biochemical manipulation medium. Similarly, [59] observed a rise in TG content at the expense of other lipid classes in nutrientlimited Monodus subterraneus.

The present results suggest that, immediately after the change in culture medium, a shift in the metabolism of C. sorokiniana was confirmed by a high percentage of TG, after which cells became acclimated and this storage lipid class returned to normal levels. According to [4], who obtained a negative correlation between TG and PL, such behavior may reflect a physiological pathway to structural lipid synthesis that is triggered under nutrient-replete conditions. In such situation, the precursors involved in both TG and PL synthesis are channeled towards the production of PL, needed in cell membranes $[5,60,61]$.

\section{Conclusions}

The $180 \mathrm{~L}$ hybrid photobioreactor (HPBR), featuring a submerged polymeric membrane, supported continuous culture of C. sorokiniana, retaining its biomass inside the photobioreactor while used medium left the culture as permeate and was replaced by fresh medium. This system provided healthy growth conditions, according to the cell proteins: carbohydrates ratios, enabling the cells to accumulate proteins. The submerged polymeric membrane system permitted exchange of medium, thus facilitating biochemical manipulation process, which resulted in a change of relative lipid composition, favoring accumulation of the neutral lipid class, triacylglycerol short after exposure to stressing condition $(24 \mathrm{~h})$. However, $48 \mathrm{~h}$ and 72 $\mathrm{h}$ later, cells acclimated themselves, with accumulation of the polar classes PL and AMPL, and triacylglycerol returned to normal values.

\section{References}

1. Douskova I, Doucha J, Livansky K, Machat J, Novak P, et al. (2009) Simultaneous flue gas bioremediation and reduction of microalgal biomass production costs. Appl Microbiol Biotechnol 82: 179-185.

2. Borowitzka M.A (2013) High-value products from microalgae -their development and commercialisation. Journal of Applied Phycology 25 : 743-756.

3. Sukenik A, Wahnon R (1991) Biochemical quality of marine unicellular algae with special emphasis on lipid composition I. Isochrysisgalbana. Aquaculture $97: 61-72$.

4. Chia AM, Lombardi AT, Melão MGM, Parrish CC (2013a). Lipid composition of Chlorellavulgaris (Trebouxiophyceae) as a function of different cadmium and phosphorus concentrations. Aquatic Toxicology 128: 171-182.

5. Chia AM, Lombardi AT, Melão MGM, Parrish CC (2013b) Effect of cadmium and nitrogen on lipid composition of Chlorella vulgaris (Trebouxiophyceae Chlorophyta). European Journal ofPhycology 48: 1-11.

6. Lombardi AT, Maldonado MT (2011) The effects of copper on the photosynthetic response of Phaeocystis cordata. Photosynth Res 108: 77-87.

7. Sukenik A, Carmeli $Y(1990)$ Lipid synthesis and fatty acid composition in Nannochloropsis sp. (Eustigmatophyceae) grown in a light-dark cycle. Journal of Phycology 26 : 463-469.

8. Fidalgo JP, Cid A, Torres E, Sukenik A, Herrero C (1998) Effects of nitrogen source and growth phase on proximate biochemical composition, lipid classes and fatty acid profile of the marine microalga Isochrysisgalbana. Aquaculture, $166: 105-116$

9. Andersen RA (2005) Algal culturing techniques, (1st edn), Elsevier Academic Press, Oxford.

10. Javanmardian M, Palsson BO (1991) High-density photoautotrophic algal cultures: design, construction, and operation of a novel photobioreactor system. Biotechnol Bioeng 38: 1182-1189.

11. Clarens AF, Resurreccion EP, White MA, Colosi LM (2010) Environmental life cycle comparison of algae to other bioenergy feedstocks. Environ Sci Techno 44: 1813-1819. 
Citation: Haneda RN, Vieira BH, Fontes SR, Ombardi G, Casali CA, et al. (2015) Biochemical Composition of Chlorella Sorokiniana Grown in a Novel Design of Hybrid Photobioreactor. J Microb Biochem Technol 7: 076-082. doi:10.4172/1948-5948.1000185

12. Starbuck CM (2011) Comment on "Environmental life cycle comparison of algae to other bioenergy feedstocks". Environ Sci Technol 45: 833.

13. Food and Agriculture Organization of the United Nations (FAO) (1996) Manual on the production anduse of live food for aquaculture. FAO Fisheries Technical Paper n. 361, Rome, Italy.

14. De Baerdemaeker T, Lemmens B, Dotremont C, Fret J, Roef L, et al. (2013) Benchmark study on algae harvesting with backwashable submerged flat panel membranes. Bioresour Technol 129: 582-591.

15. Bilad MR, Discart V, Vandamme D, Foubert I, Muylaert K, et al. (2014) Coupled cultivation and pre-harvesting of microalgae in a membrane photobioreactor (MPBR). Bioresour Technol 155: 410-417.

16. Bilad MR, Arafat HA, Vankelecom IF (2014) Membrane technology in microalgae cultivation and harvesting: a review. Biotechnol Adv 32: 1283-1300.

17. Bilad MR, Vandamme D, Foubert I, Muylaert K, Vankelecom, (2012) Harvesting microalgal biomass using submerged microfiltration membranes. Bioresource Technology 111: 343-352.

18. Discart V, Bilad MR, Marbelia L, Vankelecom (2014) Impact of changes in broth composition on Chlorella vulgaris cultivation in a membrane photobioreactor (MPBR) with permeate recycle. Bioresource Technology 152: 321-328.

19. Machado R M D, Haneda R N, Trevisan BP, Fontes S R (2012) Effect of enzymatic treatment on the cross-flow microfiltration of açai pulp: Ana lysis of the fouling and recovery of phytochemicals. Journal of Food Engineering 113: $442-452$

20. Cheryan M (1998) Ultrafiltration and Microfiltration Handbook. Technomic Publising Company, Lancaster.

21. Liu D, Wong PTS, Dutka BJ (1973) Determination of Carbohydrate in Lake Sediment by a modified Phenol-Sulfuric acid method. Water Research Pergamon Press, $7: 741-746$.

22. Bradford MM (1976) A rapid and sensitive method for the quantitation of microgram quantities of protein utilizing the principle of protein-dye binding. Anal Biochem 72: 248-254.

23. Rausch T (1981) The estimation of micro-algal protein content and its meaning to the evaluation of algal biomass I. Comparison of methods for extracting protein. Hydrobiologia78 : 237-251.

24. Parrish CC (1999) Determination of total lipid, lipid classes, and fatty acids in aquatic samples. In Lipids in Freshwater Ecosystems (Arts, M.T. \&Wainman, B.C, editors), 4-20. Spring er-Verlag, NewYork.

25. Altenburger R, Krüger J, Eisenträger A (2010) Proposing a pH stabilised nutrient medium for algal growth bioassays. Chemosphere 78: 864-870.

26. Han F, Huang J, Li Y, Wang W, Wan M, et al., (2013) Enhanced lipid productivity of Chlorella pyrenoidosa through the culture strategy of semi-continuous cultivation with nitrogen limitation and $\mathrm{pH}$ control by $\mathrm{CO}_{2}$. Bioresource Technology 136: 418-424.

27. Burlew JS (1976) Algal Culture from Laboratory to pilot plant. Carnegie Institution of Washington Publication, Washington.

28. Chiu SY, Kao CY, Chen CH, Kuan TC, Ong SC, et al. (2008) Reduction of CO2 by a high-density culture of Chlorella $\mathrm{sp}$. in a semicontinuous photobioreactor. Bioresour Technol 99: 3389-3396.

29. Bertoldi FC, Sant'Anna E, Oliveira JLB, Rebelo AM (2007) Biorremoção de nitrogênio e fósforo da soluçãohidropônica residual pormeio da microalga Chlorella vulgaris. Evidência 7: 85-92.

30. Babel S, Takizawa S (2010) Microfiltration membrane fouling and cake behavior during algal filtration. Desalination 262: 46-51.

31. Cui ZF, Chang S, Fane A G (2003) The use of gas bubbling to enhance membrane processes. Journal of Membrane Science 221: 1-35

32. Wicaksana F, Fane AG, Pongpairoj P, Field R (2012) Microfiltration of algae (Chlorella sorokiniana): Critical flux, fouling and transmission. Journal of Membrane Science,387-388: 83-92

33. Bajguz A (2011) Suppression of Chlorella vulgaris growth by cadmium, lead, and copper stress and its restoration by endogenous brassinolide. Arch Environ Contam Toxicol 60: 406-416.

34. Lai J, Yua Z, Song X, Cao X, Han X (2011) Responses of the growth and biochemical composition of Prorocentrumdonghaiense to different nitrogen and phosphorus concentrations. Journal of Experimental Marine Biology and Ecology 405: 6-17.

35. Sharma KK, Schuhmann H, Schenk PM (2012) High Lipid Induction in Microalgae for Biodiesel Production. Energies 5: 1532-1553.

36. Devi MP, Subhash GV, Mohan SV (2012) Heterotrophic cultivation of mixed microalgae for lipid accumulation and wastewater treatment during sequential growth and starvation phases: effect of nutrient supplementation. Renewable Energy 43 : 276-283.

37. Healey FP, Hendzel LL (1980) Physiological indicators of nutrient deficiency in lake phytoplankton. Canadian Journal of Fisheries and Aquatic Sciences 37: 442-453.

38. Ho SH, Huang SW, Chen CY, Hasunuma T, Kondo A, et al., (2013) Characterization and optimization of carbohydrate production from an indigenous microalga Chlorella vulgaris FSP-E. Bioresource Technology 135: 157-165.

39. Ji Y, Hu W, Li X, Ma G, Song M, et al., (2014) Mixotrophic growth and biochemical analysis of Chlorella vulgaris cultivated with diluted monosodium glutamate wastewater. Bioresource Technology,152: 471-476.

40. Rocha GS, Pinto FHV, Melão MGG, Lombard iAT (2014) Growing Scenedesmus quadricauda in used culture media: is it viable?. Journal of Applied Phycology 26: 1-8.

41. Illman AM, Scragg AH, Shales SW (2000) Increase in Chlorella strains calorific values when grown in low nitrogen medium. Enzyme Microb Technol 27: 631-635.

42. Lourenço SO, Barbarino E, Lavín PL, Lanfer Marquez UM, Aidar E (2004) Distribution of intracellular nitrogen in marine microalgae. Calculation of new nitrogen-to-protein conversion factors. European Journal of Phycology 39: 1732.

43. Zhao YF, Yu ZM, Song XX, Cao XH (2009) Biochemical compositions of two dominant bloom- forming species isolated from the Yangtze River Estuary in response to different nutrient conditions. Journal of Experimental Marine Biology and Ecology 368: 30-36.

44. Dragone G, Fernandes BD, Abreu AP, Vicente AA, Teixeira JA (2011) Nutrient limitation as a strategy for increasing starch accumulation in microalgae. Applied Energy 88: 3331-3335.

45. Rismani-Yazdi H, Haznedaroglu BZ, Bibby K, Peccia J (2011) Transcriptome sequencing and annotation of the microalgae Dunaliellatertiolecta: Pathway description and gene discovery for production of next-generation biofuels. BMC Genomics 12: 148

46. Ho SH, Chen CY, Chang JS (2012) Effect of light intensity and nitrogen starvation on $\mathrm{CO}_{2}$ fixation and lipid / carbohydrate production of an indigenous microalga Scenedesmus obliquus CNW- N. Bioresource Technology 113 244-252.

47. Lombardi AT, Vieira AAH, Sartori LA (2002) Mucilaginous capsule adsorption and intracellular uptake of copper by Kirchneriel laaperta (Chlorococcales). Journal of Phycology 38 : 332-337.

48. Ansari ZA, Amjad M (2008) Copper toxicity to algae (Chlorella vulgaris) Pakistan Journal ofScience 60: 64-66.

49. Sultan P, Shah SM, Williams P, Jan A, Ahmad N (2006) Biochemical basis of heavy metal induced stress tolerance in the $\mathrm{N}_{2}$ fixing cyanobacterium Anabaena doliolum. African Journal ofClinical and Experimental Microbiology 8: 8-22.

50. Afkar E, Ababna H, Fathi AA (2010) Toxicological Response of the Green Alga Chlorellavulgaris, to Some Heavy Metals. American Journal of Environmental Sciences 6: 230-237.

51. Hu Q, Sommerfeld M, Jarvis E, Ghirardi M, Posewitz M, et al. (2008) Microalgaltriacyl glycerols as feedstocks for biofuel production: perspectives and advances. Plant J 54: 621-639.

52. Widjaja A, Chien CC, Ju YH (2009) Study of increasing lipid production from fresh water microalgae Chlorella vulgaris. Journal of the Taiwan Institute of Chemical Engineers 40: 13-20.

53. Lynn SG, Kilham SS, Kreeger DA, Interlandi SJ (2000) Effect of nutrient availability on the biochemical and elemental stoichiometry in freshwater diatom Stephanodiscus minutulus (Bacillariophyceae). Journal of Phycology 36: 510-522.

54. Xin L, Hong-ying H, Ke G, Jia Y (2010) Growth and nutrient removal properties 
Citation: Haneda RN, Vieira BH, Fontes SR, Ombardi G, Casali CA, et al. (2015) Biochemical Composition of Chlorella Sorokiniana Grown in a Novel Design of Hybrid Photobioreactor. J Microb Biochem Technol 7: 076-082. doi:10.4172/1948-5948.1000185

of a freshwater microalga Scenedesmus sp. LX1 under different kinds of nitrogen sources. Ecological Engineering 36: 379-381.

55. Pal D, Khozin-Goldberg I, Cohen Z, Boussiba S (2011) The effect of light, salinity, and nitrogen availability on lipid production by Nannochloropsis $\mathrm{sp}$. Appl Microbiol Biotechnol 90: 1429-1441.

56. Lombardi AT, Wangersky PJ (1991) Influence of phosphorus and silicon on lipid class production by the marine diatom Chaetocerosgracilis grown in turbidostat cage cultures. Marine Ecology Progress Series 77: 39-47.

57. Lombardi AT, Wangersky PJ (1995) Particulate lipid class composition of three marine phytoplankters Chaetocerosgracilis, Isochrysisgalbana (Tahiti) and Dunaliellatertiolecta grown in batch culture. Hydrobiologia, 306: 1-6.
58. Parrish CC, Wangersky PJ (1987) Particulate and dissolved lipid classes in cultures of Phaeodactyl umtricornutum grown in cage culture turbidostats with a range of nitrogen supply rates. Marine Ecology Progress Series 35: 119-128.

59. Khozin-Goldberg I, Cohen Z (2006) The effect of phosphate starvation on the lipid and fatty acid composition of the fresh water eustigmatophyte Monodus subterraneus. Phytochemistry 67: 696-701.

60. Rodolfi L, Chini Zittelli G, Bassi N, Padovani G, Biondi N, et al. (2009) Microalgae for oil: strain selection, induction of lipid synthesis and outdoor mass cultivation in a low-cost photobioreactor. Biotechnol Bioeng 102: 100-112.

61. Griffith MJ, Harrison STL (2009) Lipid productivity as key characteristic for choosing algal species for biodiesel production. Jornal of Applied Phycology 21: 493-507. 